Special issue of the 3rd International Conference on Computational and Experimental Science and Engineering (ICCESEN 2016)

\title{
Synthesis, Characterization and Cr(VI) Adsorption Properties of Modified Magnetite Nanoparticles
}

\author{
H. Çiftçi ${ }^{a, *}$, B. ERsoY ${ }^{a}$ AND A. EvCin ${ }^{b}$ \\ ${ }^{a}$ Afyon Kocatepe University, Mining Engineering Department, Afyonkarahisar, Turkey \\ ${ }^{b}$ Afyon Kocatepe University, Material Science and Engineering Department, Afyonkarahisar, Turkey \\ In this study, magnetite $\left(\mathrm{Fe}_{3} \mathrm{O}_{4}\right)$ nanoparticles were synthesized by chemical co-precipitation method, coated \\ with silica, and then the surface of silica coated magnetite $\left(\mathrm{Fe}_{3} \mathrm{O}_{4} @ \mathrm{SiO}_{2}\right)$ nanoparticles was modified with (3- \\ aminopropyl)triethoxysilane (APTES) at first. Secondly, attained nanoparticles were characterized by the Fourier \\ transform infrared, X-ray diffraction, transmission electron microscopy, the Brunauer-Emmett-Teller, vibrating \\ sample magnetometer, and zeta-sizer devices/methods. Finally, detailed adsorption experiments were performed \\ to remove hexavalent chromium $(\mathrm{Cr}(\mathrm{VI}))$ from aqueous media by synthesized nanoparticles. Mean size and specific \\ surface area of synthesized nanoparticles were about $15 \mathrm{~nm}$ and $89.5 \mathrm{~m}^{2} / \mathrm{g}$, respectively. The highest adsorption \\ capacity among used adsorbents $\left(\mathrm{Fe}_{3} \mathrm{O}_{4}, \mathrm{Fe}_{3} \mathrm{O}_{4} @ \mathrm{SiO}_{2}, \mathrm{Fe}_{3} \mathrm{O}_{4} @ \mathrm{SiO}_{2} @ \mathrm{~L}\right)$ was attained by $\mathrm{Fe}_{3} \mathrm{O}_{4}$ nanoparticles and \\ it was determined that adsorption capacity of the other two adsorbents was too low when compared to the $\mathrm{Fe}_{3} \mathrm{O}_{4}$ \\ nanoparticles. Optimum conditions for $\mathrm{Cr}(\mathrm{VI})$ adsorption by $\mathrm{Fe}_{3} \mathrm{O}_{4}$ nanoparticles were: $\mathrm{pH}, 3$; temperature, \\ $55^{\circ} \mathrm{C}$; contact time, $90 \mathrm{~min}$; adsorbent concentration, $0.5 \mathrm{~g} / \mathrm{l}$ and initial $\mathrm{Cr}(\mathrm{VI})$ concentration $10 \mathrm{mg} / \mathrm{l}$. Under \\ these conditions, adsorption capacity and removal percentage of $\mathrm{Cr}(\mathrm{VI})$ were found to be $33.45 \mathrm{mg} / \mathrm{g}$ and $88 \%$, \\ respectively.
}

DOI: 10.12693/APhysPolA.132.564

PACS/topics: nanomagnetite, adsorption, Cr(VI), Langmuir, Freundlich, adsorption kinetics

\section{Introduction}

Nanoparticles (NPs) are of great interest in recent years due to their outstanding chemical, physical, and magnetic properties which are different from coarsegrained counterparts [1-4]. Magnetite nanoparticles $\left(\mathrm{Fe}_{3} \mathrm{O}_{4} \mathrm{NPs}\right)$ have also attracted a great attention to use as a new adsorbent, in analytical chemistry and for medicine researches with their some advantageous properties such as high surface area, low cost, high magnetic sensitivity, and high surface-active area [5]. Furthermore, $\mathrm{Fe}_{3} \mathrm{O}_{4}$ NPs are also used for some specific applications, such as drug delivery, magnetic field-assisted cancer therapy, cell labelling and sorting, magnetic resonance imaging and sensing. Like this there are various applications of $\mathrm{Fe}_{3} \mathrm{O}_{4} \mathrm{NPs}$, but they are not very stable under different environmental conditions, can turn into maghemite by oxidation and soluble in strongly acidic media [6-9]. In order to overcome these problems, the surface of $\mathrm{Fe}_{3} \mathrm{O}_{4}$ NPs can be layered with a protective material. Silica is the best known material to coat the surface of $\mathrm{Fe}_{3} \mathrm{O}_{4}$. Silica has a good mechanical and chemical stability and so silica coating provides $\mathrm{Fe}_{3} \mathrm{O}_{4}$ NPs to stay stable and prevents to dissolve in acidic media [10]. Furthermore, silica is biocompatible and there are plenty of silane groups on the silica surface. Therefore, silica coated magnetite $\left(\mathrm{Fe}_{3} \mathrm{O}_{4} @ \mathrm{SiO}_{2}\right)$ NPs can easily be modified by various functional groups [11]. The surface of $\mathrm{Fe}_{3} \mathrm{O}_{4} @ \mathrm{SiO}_{2} \mathrm{NPs}$ is negatively charged in aqueous media at low $\mathrm{pH}$ levels. In this case, the adsorption of anionic ions on the nega-

\footnotetext{
*corresponding author; e-mail: hciftci@aku.edu.tr
}

tively charged surface would be difficult because of electrostatic repulsion forces. The surface of silica can also be modified by various techniques and chemicals (especially by amine groups) to obtain positively charged surface. In this study, (3-aminopropyl)triethoxysilane was used to modify the surface of $\mathrm{Fe}_{3} \mathrm{O}_{4} @ \mathrm{SiO}_{2}$ NPs.

Chromium is one of the most important toxic and heavy metals emitted into the environment and used in various applications such as leather industry, catalyst manufacturing, paint and ink industries, ceramic and glass industry, photography, chromium-plating and production of chromium alloys or metals [12, 13]. Hexavalent chromium $\left(\mathrm{HCrO}_{4}^{-}, \mathrm{CrO}_{4}^{2-}, \mathrm{Cr}_{2} \mathrm{O}_{7}^{2-}\right)$ and trivalent chromium $\left(\mathrm{Cr}^{3+}, \mathrm{Cr}(\mathrm{OH})^{2+}\right)$ are two main chromium forms mostly occurring in the aquatic environment as a result of various processes [14]. Unlike other chromium components, hexavalent chromium $[\mathrm{Cr}(\mathrm{VI})]$ is soluble in groundwater and therefore its transportation and participation to living organisms is much more likely. Most of the components of $\mathrm{Cr}(\mathrm{VI})$ has been reported to be toxic, carcinogenic and mutagenic $[15,16]$. According to the World Health Organization (WHO) standards, maximum allowable $\mathrm{Cr}(\mathrm{VI})$ concentration in drinking waters is $0.05 \mathrm{mg} / 1[13,17]$. Thus, the amount of chromium content in the waste waters which have dangerous effect on living beings should be reduced to minimum level before releasing into the environment.

In this study, adsorption technique which is more economic, efficient, and easier technique than other techniques was used to remove $\mathrm{Cr}(\mathrm{VI})$ ions from aqueous media by magnetite and modified magnetite NPs. There is a key role of the surface properties of magnetite for $\mathrm{Cr}(\mathrm{VI})$ adsorption. In acidic media, magnetite surface becomes more positive and so anionic $\mathrm{Cr}(\mathrm{VI})$ ions can 
easily be adsorbed on the magnetite surface by the effect of electrostatic attraction forces [18]. In addition, the magnetic sensitivity of magnetite also affects the removal of $\mathrm{Cr}(\mathrm{VI})$ [19].

\section{Materials and methods 2.1. Materials}

Ammonium hydroxide $\left(\mathrm{NH}_{4} \mathrm{OH}, 28.0-30.0 \%\right)$ and 1,5-diphenylcarbazide $\left(\mathrm{C}_{13} \mathrm{H}_{14} \mathrm{~N}_{4} \mathrm{O}\right)$ were purchased from Sigma Aldrich. (3-aminopropyl)triethoxysilane $\left(\mathrm{C}_{9} \mathrm{H}_{23} \mathrm{NO}_{3} \mathrm{Si}, 98 \%\right)$ was purchased from Alfa. Iron(II) chloride hexahydrate $\left(\mathrm{FeCl}_{3} \cdot 6 \mathrm{H}_{2} \mathrm{O},>98 \%\right)$, iron(III) chloride tetrahydrate $\left(\mathrm{FeCl}_{2} \cdot 4 \mathrm{H}_{2} \mathrm{O},>99 \%\right)$, tetraethylorthosilicate $\left(\mathrm{Si}\left(\mathrm{OC}_{2} \mathrm{H}_{5}\right)_{4}, 28 \%\right)$, hydrochloric acid ( $\mathrm{HCl}, 35-37 \% \mathrm{GR}$ ), sodium hydroxide ( $\mathrm{NaOH}, 96 \%$ ), sulphuric acid $\left(\mathrm{H}_{2} \mathrm{SO}_{4}, 95-97 \%\right)$, potassium dichromate $\left(\mathrm{K}_{2} \mathrm{Cr}_{2} \mathrm{O}_{7}\right)$, acetone $\left(\mathrm{C}_{3} \mathrm{H}_{6} \mathrm{O}\right)$ and ethanol $\left(\mathrm{C}_{2} \mathrm{H}_{5} \mathrm{OH}\right.$, $99.7 \%)$ were purchased from Merck.

$\mathrm{Cr}(\mathrm{VI})$ stock solution $(500 \mathrm{mg} / \mathrm{l})$ was prepared by dissolving $1.414 \mathrm{~g} \mathrm{~K}_{2} \mathrm{Cr}_{2} \mathrm{O}_{7}$ with $1000 \mathrm{ml}$ distilled water. 1.5-DPC $(0.5 \%)$ solution was used for UV measurements and prepared by dissolving $0.25 \mathrm{~g}$ 1.5-diphenylcarbazide with $50 \mathrm{ml}$ acetone. $6 \mathrm{~N}$ sulphuric acid solution was prepared by adding $8.33 \mathrm{ml} \mathrm{H}_{2} \mathrm{SO}_{4}(98 \%)$ into $50 \mathrm{ml}$ distilled water to be used to $\mathrm{pH}$ adjustments at UV measurements.

\subsection{Synthesis of nanoparticles}

In this study, modified Massart technique was used to synthesize magnetite NPs [20]. Briefly, $0.02 \mathrm{~mol}$ $\mathrm{FeCl}_{3} \cdot 6 \mathrm{H}_{2} \mathrm{O}$ and $0.01 \mathrm{~mol} \mathrm{FeCl}_{2} \cdot 4 \mathrm{H}_{2} \mathrm{O}$ were dissolved with $100 \mathrm{ml}$ distilled water in a five-necked flask at room temperature. Dissolution and stirring was carried out for $30 \mathrm{~min}$ at $750 \mathrm{rpm}$ using a mechanical stirrer. Then $50 \mathrm{ml}$ of $28 \%$ concentrated $\mathrm{NH}_{4} \mathrm{OH}$ was added dropwise $(3.3 \mathrm{ml} / \mathrm{min})$ into the solution. After that the solution temperature was increased to $90^{\circ} \mathrm{C}$ and stirring was continued for $2 \mathrm{~h}$. Finally, the obtained magnetite NPs precipitate was separated from solution using a magnet, washed distilled water and ethanol several times and stored at $1 \%$ concentration in ethanol. $\mathrm{Fe}_{3} \mathrm{O}_{4} @ \mathrm{SiO}_{2} \mathrm{NPs}$ were prepared according to the Stöber method by applying some changes $[10,21] .50 \mathrm{ml}$ of previously prepared magnetite liquid (1\%) was dispersed ultrasonically and then added into a $500 \mathrm{ml}$ three-necked flask which contained $40 \mathrm{ml}$ distilled water, $120 \mathrm{ml}$ ethanol, and $5 \mathrm{ml}$ $\mathrm{NH}_{4} \mathrm{OH}(28 \%)$. The mixture was stirred for $30 \mathrm{~min}$ at $25^{\circ} \mathrm{C}$ and $800 \mathrm{rpm}$ using a mechanical stirrer and after stirring $0.4 \mathrm{ml}$ TEOS was added into the mixture very slowly $(0.013 \mathrm{ml} / \mathrm{min})$. After adding TEOS, stirring was continued for another $4 \mathrm{~h}$ under the same conditions. Finally, the silica coated magnetite NPs were taken from solution by a magnet, washed distilled water and ethanol several times and stored at $1 \%$ concentration in ethanol. In order to prepare amine modified NPs $\left(\mathrm{Fe}_{3} \mathrm{O}_{4} @ \mathrm{SiO}_{2} @ \mathrm{~L}\right)$, the following method was summarized. $\quad 150 \mathrm{mg} \mathrm{Fe}_{3} \mathrm{O}_{4} @ \mathrm{SiO}_{2}$ powder was put in a $100 \mathrm{ml}$ beaker which contained $50 \mathrm{ml}$ ethanol and the mixture dispersed ultrasonically at $80 \mathrm{~W}$ for $2 \mathrm{~min}$. After that $1 \mathrm{ml}$ APTES was added into the mixture and stirred for $3 \mathrm{~h}$ at $50^{\circ} \mathrm{C}$. After stirring, modified NPs were separated from solution and dried for $4 \mathrm{~h}$ at $65^{\circ} \mathrm{C}$. All synthesis processes were performed under $\mathrm{N}_{2}$ gas to prevent oxidation of NPs. A schematic summary of the synthesis steps is given in Fig. 1 .

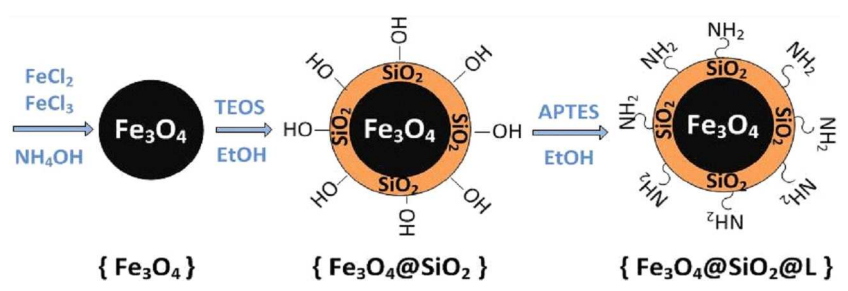

Fig. 1. Schematic illustration of summarized synthesis process of NPs.

\subsection{Characterization methods}

The morphology and size of NPs were observed using JEM 2100F (JEOL) transmission electron microscope (TEM). To determine the functional groups of NPs, the Fourier transform infrared (FTIR) spectra were recorded on a Perkin-Elmer Spectrum BX spectrometer with the $\mathrm{KBr}$ technique in the range of $400-4000 \mathrm{~cm}^{-1}$. Magnetic sensitivities were determined by using $1.2 \mathrm{H}$ vibrating sample magnetometer VSM (LDJ 9600) at $200 \mathrm{kV}$ accelerated voltage. To understand the crystal structure of NPs, Bruker D8 advance X-ray diffraction device (XRD) was used with $\mathrm{Cu} K_{\alpha}$ radiation. The specific surface area of NPs was determined using Micromeritics Gemini 2360 by the Brunauer, Emmett and Teller (BET) method [22]. Zeta potential $(\zeta)$ measurements were performed using Malvern Nano-Z zetasizer. To perform $\zeta$ measurements $0.01 \mathrm{~g}$ of sample with $100 \mathrm{ml} 10^{-3} \mathrm{M} \mathrm{NaCl}$ solution were put in a beaker and the mixture was dispersed ultrasonically for $3 \mathrm{~min}$. Then, $\mathrm{pH}$ of mixture was adjusted using previously prepared $0.1-5 \mathrm{M} \mathrm{HCl}$ and $0.1-1 \mathrm{M} \mathrm{NaOH}$ solutions and $\zeta$ measurements were performed for each sample.

\subsection{Adsorption experiments}

Batch adsorption experiments were performed in a $100 \mathrm{ml}$ erlenmayer which contained $50 \mathrm{ml} \mathrm{Cr}(\mathrm{VI})$ solution of known concentration and desired amount of adsorbent. The mixture was stirred using a GFL-1086 shaking water bath at $175 \mathrm{rpm}$. After that the adsorbent was taken from solution by magnetic separation using a magnet and the solution analysed for the residual Cr(VI) ions by Shimadzu UV-1240 spectrophotometer. Determination of $\mathrm{Cr}(\mathrm{VI})$ ions was performed as follows. $40 \mathrm{ml}$ of sample was taken in a beaker and $3 \mathrm{ml}$ of $6 \mathrm{~N} \mathrm{H}_{2} \mathrm{SO}_{4}$ was added into the solution to decrease the $\mathrm{pH}$ of the solution under 2 . Then $0.8 \mathrm{ml}$ of $0.5 \% \mathrm{DPC}$ solution was added to the mixture. After waiting for $5 \mathrm{~min}$, the UV measurements were performed [23]. Percentage removal of $\mathrm{Cr}(\mathrm{VI})$ and amount of adsorption at equilibrium, $q_{e}(\mathrm{mg} / \mathrm{g})$, were calculated by using following Eqs. (1) and (2):

$$
\operatorname{Removal}(\%)=\frac{C_{i}-C_{e}}{C_{i}} \times 100 \%
$$




$$
q_{e}=\frac{C_{i}-C_{e}}{m} \times V,
$$

where $C_{i}$ and $C_{e}$ are the initial and final concentration of $\mathrm{Cr}(\mathrm{VI})$ ions $(\mathrm{mg} / \mathrm{l})$ in the solution, respectively. $V$ is the volume (l) of tested solution and $m$ is the mass of used adsorbent $(\mathrm{g})$.

\section{Results and discussion}

\subsection{Characterization of synthesized nanoparticles}

FTIR spectrum of synthesized NPs is displayed in Fig. 2. Strong adsorption band around $570-580 \mathrm{~cm}^{-1}$ wavelength proves the presence of $\mathrm{Fe}_{3} \mathrm{O}_{4}$ NPs for both spectra. This band is interpreted to stretching vibrations of $\mathrm{Fe}^{2+}$ and $\mathrm{Fe}^{3+}$ ions in tetrahedral regions and $\mathrm{Fe}^{3+}$ ions in octahedral regions of magnetite [8]. The absorption bands at $945 \mathrm{~cm}^{-1}$ and $1094 \mathrm{~cm}^{-1}$ wavelength observed in Fig. $2 \mathrm{~b}$ are a result of $\mathrm{Si}-\mathrm{O}-\mathrm{Si}$ and $\mathrm{Si}-\mathrm{O}-\mathrm{H}$ stretching vibrations. The extra peak seen at $800 \mathrm{~cm}^{-1}$ wavelength is due to the $\mathrm{Si}-\mathrm{O}$ vibration [24]. These results indicate that the magnetite NPs was successfully coated by silica. The wide bands around $3440 \mathrm{~cm}^{-1}$ wavelength are attributed to $\mathrm{O}-\mathrm{H}$ stretching vibrations of free water molecules, hydroxyl groups $(\mathrm{OH})$ on the surface, or water molecules absorbed by the material $[8,9]$.

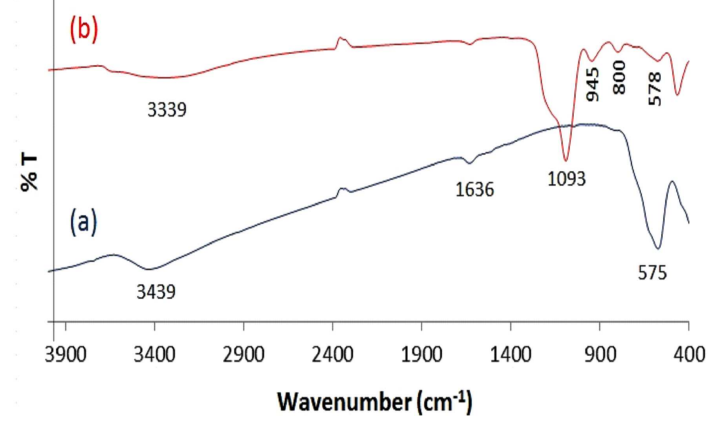

Fig. 2. FTIR spectra of $\mathrm{Fe}_{3} \mathrm{O}_{4}$ NPs (a) and $\mathrm{Fe}_{3} \mathrm{O}_{4} @ \mathrm{SiO}_{2} \mathrm{NPs}(\mathrm{b})$.

TEM images of the NPs were shown in Fig. 3. The average particle size of $\mathrm{Fe}_{3} \mathrm{O}_{4}$ NPs was estimated to be $15 \mathrm{~nm}$ and silica shell thickness was not clearly seen because of very thin coating. Therefore, surface coating and modification have no significant effect in size and morphology of $\mathrm{Fe}_{3} \mathrm{O}_{4}$ NPs. The NPs has approximately spherical shape as seen in the figure.

Figure 4 shows the XRD pattern of NPs. Large peaks show nanocrystalline and sharp peaks show the high degree of crystalline structure $[8,25]$. As seen in the figure, crystalline diffraction peaks with $2 \theta$ at $30.1^{\circ}, 35.4^{\circ}$, $43.2^{\circ}, 53.9^{\circ}, 57.2^{\circ}$ and $62.7^{\circ}$ correspond to the characteristic planes [(220), (311), (400), (422), (511), (440)] of cubic spinel $\mathrm{Fe}_{3} \mathrm{O}_{4}$, respectively (JCPDS No. 01-0716336). The same results observed in Fig. $4 \mathrm{~b}$ indicate the presence of magnetite crystals. As shown in XRD pattern of $\mathrm{Fe}_{3} \mathrm{O}_{4} @ \mathrm{SiO}_{2} @ \mathrm{~L} \mathrm{NPs}$, less intense and larger peaks are a result of silica coating and amine modification of the magnetite surface [26].

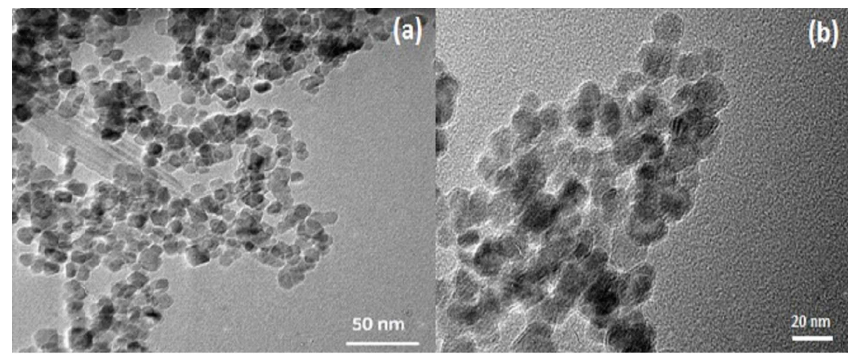

Fig. 3. TEM micrographs of $\mathrm{Fe}_{3} \mathrm{O}_{4}$ NPs (a) and $\mathrm{Fe}_{3} \mathrm{O}_{4} @ \mathrm{SiO}_{2} @ \mathrm{~L}$ NPs (b).

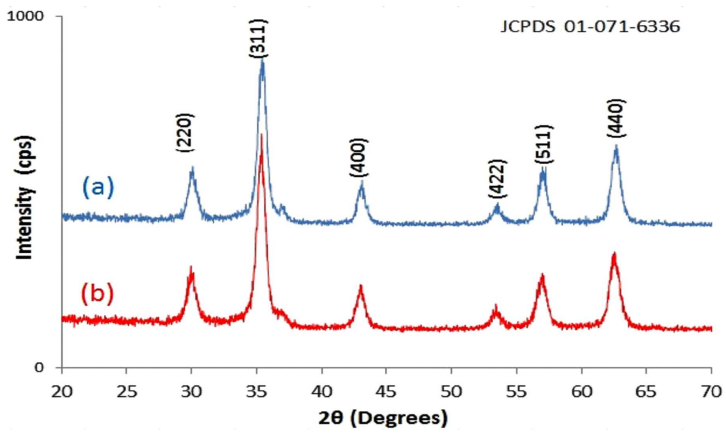

Fig. 4. XRD patterns of $\mathrm{Fe}_{3} \mathrm{O}_{4}$ NPs (a) and $\mathrm{Fe}_{3} \mathrm{O}_{4} @ \mathrm{SiO}_{2} @ L$ NPs (b).

Magnetization curves of synthesized NPs are given in Fig. 5. Magnetization saturations $\left(M_{s}\right)$ of $\mathrm{Fe}_{3} \mathrm{O}_{4}$ and $\mathrm{Fe}_{3} \mathrm{O}_{4} @ \mathrm{SiO}_{2} @ \mathrm{~L}$ NPs were found to be $75 \mathrm{emu} / \mathrm{g}$ and $37 \mathrm{emu} / \mathrm{g}$, respectively. As expected, the magnetization saturation of $\mathrm{Fe}_{3} \mathrm{O}_{4} @ \mathrm{SiO}_{2} @ \mathrm{~L}$ NPs measured was lower and this is a result of diamagnetic silica shell mass surrounding the magnetite NPs. But, $37 \mathrm{emu} / \mathrm{g}$ is still sufficient for magnetic separation of NPs by a magnet from a solution. Another result shown in Fig. 5 is that both magnetization curves go through exactly the origin of magnetization graph. This means that the synthesized NPs show superparamagnetic behaviour at room temperature because of not exhibiting hysteresis, coercivity, and remanence [27].

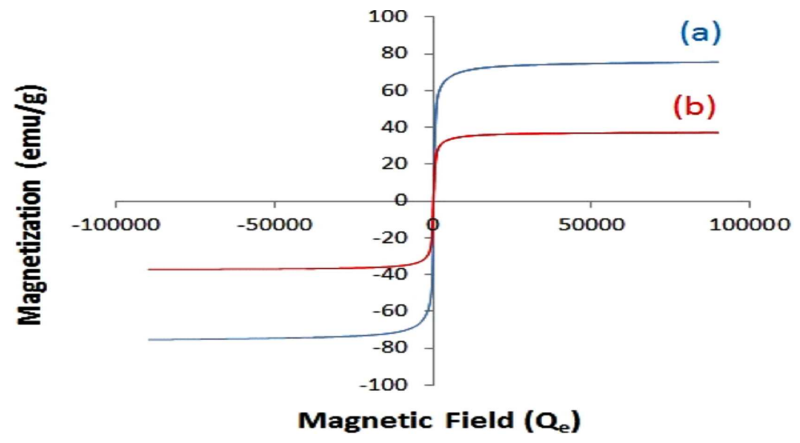

Fig. 5. Magnetization curves of (a) $\mathrm{Fe}_{3} \mathrm{O}_{4}$ and (b) $\mathrm{Fe}_{3} \mathrm{O}_{4} @ \mathrm{SiO}_{2} @ \mathrm{~L}$ NPs.

In order to determine the surface charge of NPs, $\zeta$ measurements as a function of $\mathrm{pH}$ are presented in Fig. 6 . As seen in the figure, the isoelectric point (iep) of $\mathrm{Fe}_{3} \mathrm{O}_{4}$ 
NPs was found to be 6.8 which is compatible with literature values $[8,27,28]$. The $\mathrm{Fe}_{3} \mathrm{O}_{4} @ \mathrm{SiO}_{2} \mathrm{NPs}_{\mathrm{s}}$ showed an iep of 2.2 close to that of amorphous silica [29] and the iep of $\mathrm{Fe}_{3} \mathrm{O}_{4} @ \mathrm{SiO}_{2} @ \mathrm{~L}$ NPs was measured to be 8.4. These different results prove that silica coating and amine modification of magnetite NPs surface were successfully performed.

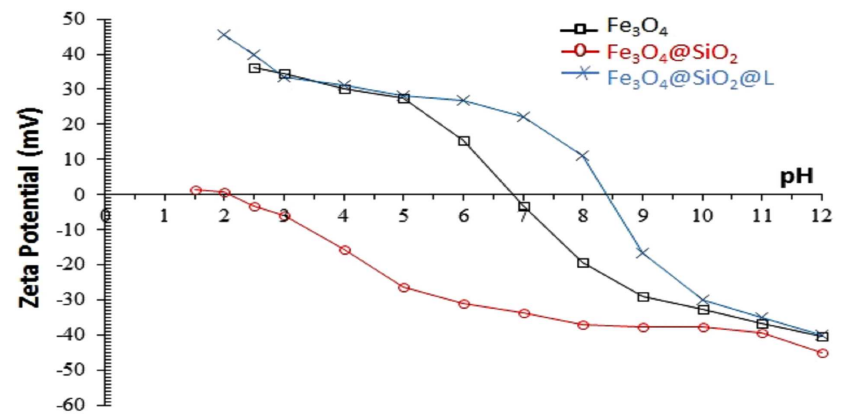

Fig. 6. Zeta potential $(\zeta)$ measurements of NPs as a function of $\mathrm{pH}$.

\subsection{Comparison of prepared NPs according to their adsorption capacities}

Adsorption experiments at different initial Cr(VI) concentrations were performed to compare the adsorption capacities of NPs and obtained comparative results are shown in Fig. 7. When adsorption experiments were performed, the temperature was $25^{\circ} \mathrm{C}$, contact time: $90 \mathrm{~min}$, adsorbent concentration: $0.5 \mathrm{~g} / \mathrm{l}$, and $\mathrm{pH}$ was kept at 2. As clearly shown in the figure, adsorption capacity of $\mathrm{Fe}_{3} \mathrm{O}_{4} @ \mathrm{SiO}_{2}$ and $\mathrm{Fe}_{3} \mathrm{O}_{4} @ \mathrm{SiO}_{2} @ \mathrm{~L} \mathrm{NPs}(1.0 \mathrm{mg} / \mathrm{g}$ and $3.2 \mathrm{mg} / \mathrm{g}$, respectively) was found to be much lower than $\mathrm{Fe}_{3} \mathrm{O}_{4} \mathrm{NPs}(25 \mathrm{mg} / \mathrm{g})$. Therefore, $\mathrm{Fe}_{3} \mathrm{O}_{4}$ adsorbent was selected to perform the next detailed adsorption experiments.

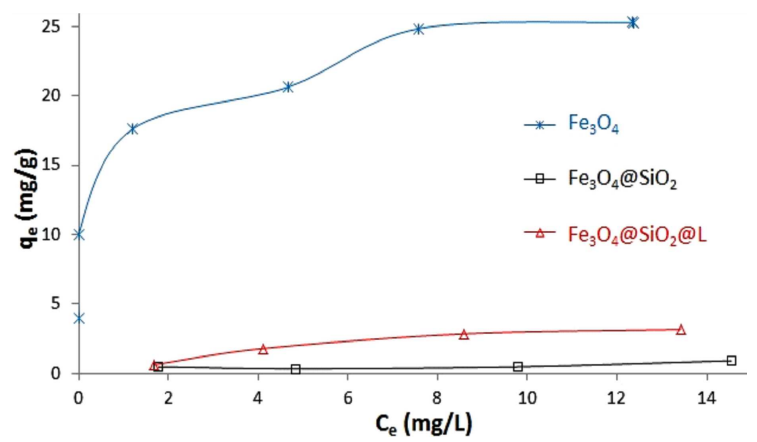

Fig. 7. $\mathrm{Cr}(\mathrm{VI})$ adsorption capacities of prepared NPs (adsorption conditions: initial concentration of $\mathrm{Cr}(\mathrm{VI})$ $10 \mathrm{mg} / \mathrm{l}$, adsorbent dose $0.5 \mathrm{~g} / \mathrm{l}$, contact time $24 \mathrm{~h}$, temperature $25^{\circ} \mathrm{C}$ ).

\subsection{Effect of $p H$}

Figure 8 shows the effect of $\mathrm{pH}$ on the adsorption of $\mathrm{Cr}(\mathrm{VI})$ ions by $\mathrm{Fe}_{3} \mathrm{O}_{4}$ NPs. Maximum removal percentage of $\mathrm{Cr}(\mathrm{VI})(88 \%)$ was found at $\mathrm{pH}$ range $2-3$. As clearly seen in the figure, the increase of $\mathrm{pH}$ resulted in a sharp decrease of $\mathrm{Cr}(\mathrm{VI})$ removal. The dominant form of $\mathrm{Cr}(\mathrm{VI})$ at 2-20 mg/l concentrations and acidic $\mathrm{pH}$ levels is $\mathrm{HCrO}_{4}$ which occurs from the hydrolysis reaction of the $\mathrm{Cr}_{2} \mathrm{O}_{7}^{2-}$ ions. If $\mathrm{pH}$ value becomes greater than $6.5, \mathrm{CrO}_{4}^{2-}$ ions are seen as dominant $\mathrm{Cr}(\mathrm{VI})$ form [30]. Electrostatic attractive forces between the positively surface charged adsorbent and anionic adsorbate $\left(\mathrm{HCrO}^{-4}\right)$ are the main cause of the high adsorption amount at acidic $\mathrm{pH}$ levels. $\mathrm{pH} 3$ was selected as optimum value for the further experiments. The iep of adsorbent $\left(\mathrm{Fe}_{3} \mathrm{O}_{4}\right)$ was found to be 5.8. Therefore, the surface of adsorbent is negatively charged at $\mathrm{pH}$ higher than 5.8 and so adsorption of $\mathrm{Cr}(\mathrm{VI})$ becomes difficult due to electrostatic repulsion forces.

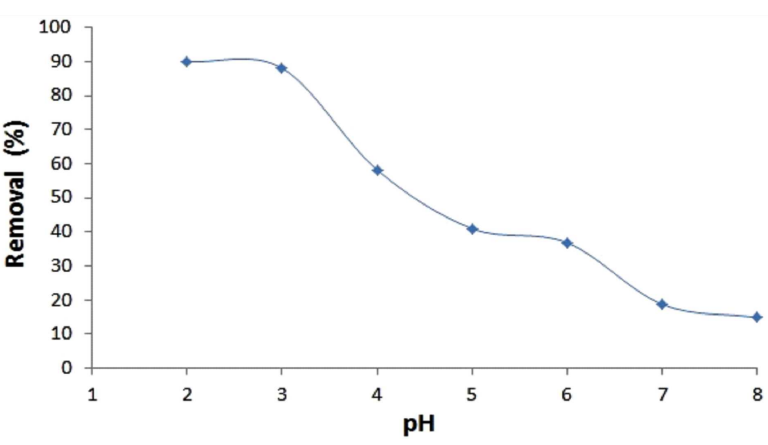

Fig. 8. Effect of $\mathrm{pH}$ on the removal of $\mathrm{Cr}(\mathrm{VI})$ by $\mathrm{Fe}_{3} \mathrm{O}_{4}$ NPs (adsorption conditions: initial concentration of $\mathrm{Cr}(\mathrm{VI}) 10 \mathrm{mg} / \mathrm{l}$, adsorbent dose $0.5 \mathrm{~g} / \mathrm{l}$, contact time $24 \mathrm{~h}$, temperature $25^{\circ} \mathrm{C}$ ).

\subsection{Effect of adsorbent dose}

The effect of adsorbent dose on removal of $\mathrm{Cr}(\mathrm{VI})$ ions from solution is demonstrated in Fig. 9. Experimental results showed that the percentage removal of $\mathrm{Cr}(\mathrm{VI})$ increased from $42.5 \%$ to $100 \%$ with increasing amount of adsorbent dose from $0.2 \mathrm{~g} / 1$ to $0.8 \mathrm{~g} / \mathrm{l}$. This can be explained with increase of effective surface area on which metal ions will be adsorbed. On the other hand, the adsorption capacity $(\mathrm{mg} / \mathrm{g})$ was continuously decreased with increase of adsorbent dose and this situation is a result of remaining of effective surface area without saturation along with the adsorption process. Similar results were also observed in the other experiments using different adsorbents to removal of $\mathrm{Cr}(\mathrm{VI})$ [15, 31]. When viewed economically, $0.5 \mathrm{~g} / \mathrm{l}$ was selected as optimum adsorbent dose for the next experiments.

\subsection{Effect of initial $\mathrm{Cr}(V I)$ concentration and contact time}

Figure 10 shows the change in adsorption capacity with the change of initial $\mathrm{Cr}(\mathrm{VI})$ concentration from 5 to $25 \mathrm{mg} / \mathrm{l}$ and contact time up to $150 \mathrm{~min}$. As it is expected, a rapid increase in the adsorption capacity was observed in the first stage and then this increase was slowed down until adsorption process reached the equilibrium time. Adsorption capacity increased from $17.4 \mathrm{mg} / \mathrm{g}$ to $24.9 \mathrm{mg} / \mathrm{g}$ when percentage removal decreased from $87.5 \%$ to $62.2 \%$ by increase of the initial 


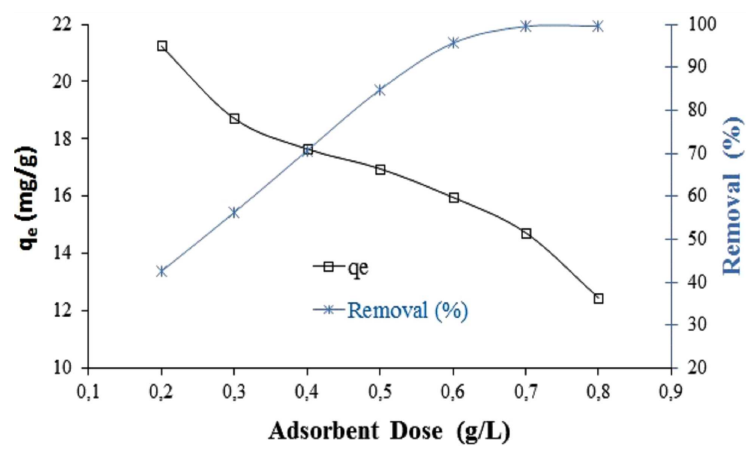

Fig. 9. Effect of adsorbent dose on the removal of $\mathrm{Cr}(\mathrm{VI})$ by $\mathrm{Fe}_{3} \mathrm{O}_{4}$ NPs (adsorption conditions: initial concentration of $\mathrm{Cr}(\mathrm{VI}) 10 \mathrm{mg} / \mathrm{l}$, contact time $90 \mathrm{~min}$, temperature $\left.25^{\circ} \mathrm{C}, \mathrm{pH} 3\right)$.

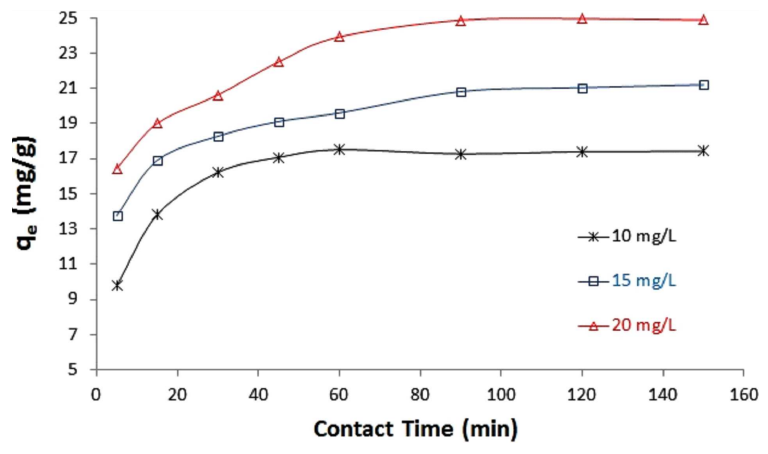

Fig. 10. Effect of contact time and initial $\mathrm{Cr}(\mathrm{VI})$ concentration on the removal of $\mathrm{Cr}$ (VI) by $\mathrm{Fe}_{3} \mathrm{O}_{4}$ NPs (adsorption conditions: amount of adsorbent $0.5 \mathrm{~g} / \mathrm{l}$, temperature $\left.25^{\circ} \mathrm{C}, \mathrm{pH} 3\right)$.

$\mathrm{Cr}(\mathrm{VI})$ concentration from $10 \mathrm{mg} / \mathrm{l}$ to $20 \mathrm{mg} / \mathrm{l}$. This situation can be explained by the mass transfer rate resulted from growing driving force [32]. Additionally, the curves reaches an equilibrium at $90 \mathrm{~min}$ and initial $\mathrm{Cr}(\mathrm{VI})$ concentration has no effect on the equilibrium time. According to these results, it can be said that the adsorption of $\mathrm{Cr}(\mathrm{VI})$ on the surface of $\mathrm{Fe}_{3} \mathrm{O}_{4}$ NPs is monolayer [33].

\subsection{Effect of temperature}

Effect of temperature on $\mathrm{Cr}(\mathrm{VI})$ removal as a function of initial chromium concentration is illustrated in Fig. 11. As seen clearly from figure, the adsorption capacity $(\mathrm{mg} / \mathrm{g})$ increased with increase of temperature and this result indicates that the adsorption of $\mathrm{Cr}(\mathrm{VI})$ on $\mathrm{Fe}_{3} \mathrm{O}_{4}$ NPs is a endothermic process. When the adsorption process reached equilibrium, maximum adsorption capacities at 25 and 55 degrees was found to be $25 \mathrm{mg} / \mathrm{g}$ and $35 \mathrm{mg} / \mathrm{g}$, respectively.

\subsection{Adsorption mechanism}

In this study, the target ions were the $\mathrm{HCrO}_{4}$ ions which are the dominant form of $\mathrm{Cr}(\mathrm{VI})$ ions at 10 $25 \mathrm{mg} / \mathrm{l}$ initial concentration range and $\mathrm{pH} 3$. In aqueous media, $\mathrm{FeOH}_{2}^{+}$functional groups are formed on the surface of $\mathrm{Fe}_{3} \mathrm{O}_{4} \mathrm{NPs}$ [34]. Adsorption of $\mathrm{HCrO}_{4}$ ions on the $\mathrm{Fe}_{3} \mathrm{O}_{4}$ NPs is a physicochemical process according to other studies. Namely, $\mathrm{Cr}(\mathrm{VI})$ ions are adsorbed

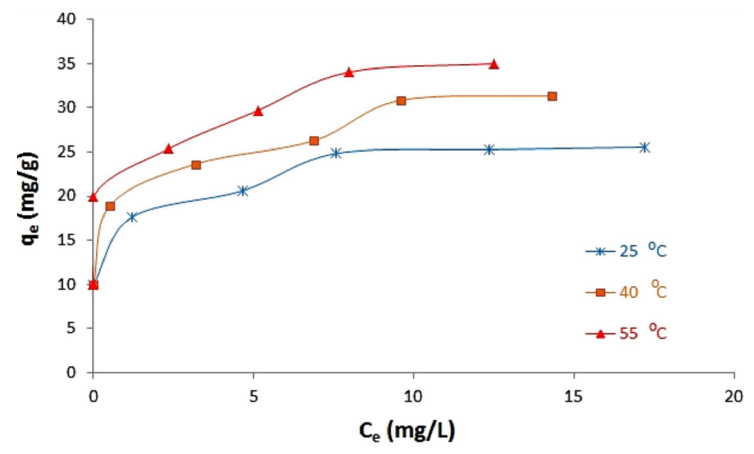

Fig. 11. Effect of temperature on the removal of $\mathrm{Cr}(\mathrm{VI})$ by $\mathrm{Fe}_{3} \mathrm{O}_{4}$ NPs (adsorption conditions: initial concentration of $\mathrm{Cr}(\mathrm{VI}) 10 \mathrm{mg} / \mathrm{l}$, contact time $90 \mathrm{~min}$, adsorbent concentration $0.5 \mathrm{~g} / \mathrm{l}, \mathrm{pH} 3)$.

physically on the surface of $\mathrm{Fe}_{3} \mathrm{O}_{4}$ NPs by electrostatic attraction forces and then reduced to $\mathrm{Cr}(\mathrm{III})$ by redox reactions [35-37]. After physical adsorption process, chemical adsorption happens by electron exchange between $\mathrm{FeOH}_{2}^{+}$and $\mathrm{HCrO}_{4}$ ions, and $\mathrm{Cr}(\mathrm{VI})$ ions are reduced to non-toxic $\mathrm{Cr}(\mathrm{III})$ forms. Another way to understand this physical or chemical mechanism of the adsorption is calculation of adsorption energy. If adsorption energy becomes in the range of $1-2 \mathrm{~kJ} / \mathrm{mol}$, physical adsorption process is observed. $20-40 \mathrm{~kJ} / \mathrm{mol}$ adsorption energy levels show the chemical adsorption process [38]. According to thermodynamic calculations in this study the adsorption energy $\left(E_{a}\right.$ or $\left.\Delta H^{\circ}\right)$ was found to be $23.45 \mathrm{~kJ} / \mathrm{mol}$. Therefore, we can say that the adsorption of $\mathrm{Cr}(\mathrm{VI})$ ions onto the $\mathrm{Fe}_{3} \mathrm{O}_{4}$ NPs is a chemical process.

\section{Conclusion}

$\mathrm{Fe}_{3} \mathrm{O}_{4}$ NPs have been shown to be an effective adsorbent for adsorption of $\mathrm{Cr}(\mathrm{VI})$ when compared to $\mathrm{Fe}_{3} \mathrm{O}_{4} @ \mathrm{SiO}_{2}$ and $\mathrm{Fe}_{3} \mathrm{O}_{4} @ \mathrm{SiO}_{2} @ \mathrm{~L}$ NPs. Electrostatic attraction forces between $\mathrm{Cr}(\mathrm{VI})$ ions and magnetite NPs play a key role for the $\mathrm{Cr}(\mathrm{VI})$ removal. The adsorption process was found to be strongly dependent on $\mathrm{pH}$, contact time, adsorbent dose, and initial $\mathrm{Cr}(\mathrm{VI})$ concentration. Maximum $\mathrm{Cr}(\mathrm{VI})$ adsorption capacity was found to be $33.45 \mathrm{mg} / \mathrm{g}$ with $88 \%$ removal at $\mathrm{pH} 3.0$. According to these results, $\mathrm{Fe}_{3} \mathrm{O}_{4}$ NPs can be used as an effective adsorbent for removal of $\mathrm{Cr}(\mathrm{VI})$ ions from industrial waste waters. Additionally, the magnetic separation of $\mathrm{Fe}_{3} \mathrm{O}_{4}$ NPs from solution is more rapid, simpler, and more effective than other solid-liquid separation techniques.

\section{Acknowledgments}

This study was financially supported by Afyon Kocatepe University, Scientific Research Projects (BAP), Project No. 14.FEN.BIL.33.

\section{References}

[1] W. Laslouni, Z. Hamlati, M. Azzaz, Acta Phys. Pol. A 128, B-190 (2015).

[2] W. Laslouni, M. Azzaz, Acta Phys. Pol. A 130, 112 (2016). 
[3] H. Mutuk, T. Mutuk, H. Gümüs, B. Mesci Oktay, Acta Phys. Pol. A 130, 172 (2016).

[4] F. Göde, F. Yavuz, I.A. Kariper, Acta Phys. Pol. A 128, B-215 (2015).

[5] A.F. Ngomsik, A. Bee, M. Draye, G. Cote, V. Cabuil, Compt. Rend. Chim. 8, 963 (2005).

[6] H. Bagheri, A. Afkhami, M. Saber-Tehrani, H. Khoshsafar, Talanta 97, 87 (2012).

[7] F. Fajaroh, H. Setyawan, A. Nur, W. Lenggoro, Adv. Powd. Technol. 24, 507 (2013).

[8] M.H. Farimani, N. Shahtahmasebi, M. Rezaee Roknabadi, N. Ghows, A. Kazemi, Physica E 53, 207 (2013).

[9] Y.S. Li, J.S. Church, A.L. Woodhead, F. Moussa, Spectrochim. Acta A 76, 484 (2010).

[10] Y.H. Deng, C.C. Wang, J.H. Hu, W.L. Yang, S.K. Fu, Coll. Surf. A Physicochem. Eng. Asp. 262, 87 (2005).

[11] Y. Xu, Y. Zhou, W. Ma, J. Nanopart. Res. 15, 1716 (2013).

[12] W. Slooff, Integrated Criteria Document Chromium, Report no. 758701002, National Institute of Public Health and Environmental Protection, Bilthoven, Netherlands 1989.

[13] World Health Organization (WHO), Chromium, Environmental Health Criteria, No. 61, Geneva 1988.

[14] U. Förstner, G.T.W. Wittmann, Metal Pollution in the Aquatic Environment, 2nd ed., Springer-Verlag, Berlin 1981.

[15] H. Li, Z. Li, T. Liu, X. Xiao, Z. Peng, L. Deng, Biores. Technol. 99, 6271 (2008).

[16] A.E. Sikaily, A.E. Nemr, A. Khaled, O. Abdelwehab, J. Hazard. Mater. 148, 216 (2007).

[17] World Health Organization (WHO), Guidelines for drinking-water quality, 3rd ed., Geneva 1:334, 2004.

[18] M.M. Amin, A. Khodabakhshi, M. Mozafari, B. Bina, S. Kheiri, Environ. Eng. Manag. J. 9, 921 (2010).

[19] J. Hu, I.M.C. Lo, G. Chen, Water Sci. Technol. 50 , 139 (2004).

[20] R. Massart, IEEE Trans. Magn. 17, 1247 (1981).

[21] W. Stöber, A. Fink, E. Bohn, J. Coll. Interf. Sci. 26, 62 (1968).
[22] S. Brunauer, P.H. Emmett, E. Teller, J. Am. Chem. Soc. 60, 309 (1938)

[23] APHA, Standard Methods for the Examination of Water and Wastewater, 19th ed., American Public Health Association, Washington, DC 1995.

[24] K. Nakamoto, Infrared Spectra of Inorganic and Coordination Compounds, 2nd ed., Wiley, London 1970.

[25] A. Evcin, N.Ç. Bezir, R. Kayalı, M. Kasıkçı, A. Oktay, Acta Phys. Pol. A 128, B-303 (2015).

[26] S. Sadeghi, H. Azhdari, H. Arabi, A.Z. Moghaddam, J. Hazard. Mater. 215, 208 (2012).

[27] X. Zhao, Y. Shi, T. Wang, Y. Cai, G. Jiang, J. Chro matogr. A 1188, 140 (2008).

[28] S. Wang, J. Tang, H. Zhao, J. Wana, K. Chen, J. Coll. Interf. Sci. 432, 43 (2014).

[29] J. Wang, S. Zheng, Y. Shao, J. Liu, Z. Xu, D. Zhu, J. Coll. Interf. Sci. 349, 293 (2010).

[30] D. Mohan, C.U. Pittman, Jr., J. Hazard. Mater. B 137, 762 (2006)

[31] H. Zhang, Y. Tang, D. Cai, X. Liu, X. Wang, Q. Huang, Z. Yu, J. Hazard. Mater. 181, 801 (2010).

[32] U.K. Garg, M.P. Kaur, V.K. Garg, D. Sud, Biores. Technol. 99, 1325 (2008).

[33] C. Namasivayam, D. Sangeetha, J. Hazard. Mater. 135, 449 (2006).

[34] K. Fukushi, T. Sato, Environ. Sci. Technol. 39, 1250 (2005).

[35] Y. Jung, J. Choi, W. Lee, Chemosphere 68, 1968 (2007).

[36] P. Yuan, D. Liu, M. Fan, D. Yang, R. Zhu, F. Ge, J.X. Zhu, H. He, J. Hazard. Mater. 173, 614 (2010).

[37] P. Yuan, M. Fan, D. Yang, H. He, D. Liu, A. Yuan, J. Zhu, T. Chen, J. Hazard. Mater. 166, 821 (2009).

[38] W. Rieman, H. Walton, Ion-Exchange in Analytical Chemistry, International Series of Monographs in Analytical Chemistry, Vol. 38, Pergamon Press, Oxford 1970. 